\section{Including Native American Perspectives in the Political Science Curriculum}

\author{
Franke Wilmer, Montana State University \\ Michael E. Melody, Barry University \\ Margaret Maier Murdock, University of Wyoming
}

Both native and nonnative Ameri-
cans recognized 1992 as a quincen-
tennial year. But while many
Americans of European ancestry
celebrated their "discovery" of this
hemisphere in which they are now
the dominant culture, Native Amer-
icans celebrated their survival de-
spite five centuries of genocide and
ethnocide. The rhetoric and discus-
sion of these perspectives will con-
tinue long past the quincentenniary. However, the significance of these differing perspectives is not which one is considered historically correct. Rather, each perspective must be studied for what it teaches about each people's conception of the public things, politics. There is, indeed, much to learn.

The worst kind of elitism is that which ignores other cultures, other peoples, other political or economic systems. By ignoring those who are different, stigmatized as "other," we not only deny their existence, but also recognize no dignity or value in these "others." The discipline of political science has certainly been guilty of such neglect with regard to Native Americans (Melody and Murdock 1987; McCulloch 1989). In political science we have largely left the study of native peoples and their political systems to sociologists and anthropologists and have, therefore, denied the role that indigenous peoples have played in the development of the American political system as well as the role they continue to play in the political and economic processes of this country. This neglect has even led us to ignore the existence of tribal governments as autonomous entities in intergovernmental relationships within the American political system (Melody 1980).

The quincentenniary provided political scientists with an opportunity to overcome this ethnocentric neglect. It was a chance to help ourselves and our students understand the greater reality of different ways of living in community which, in turn, promotes tolerance, an essential factor in our multicultural democracy. It was a chance to recognize the existence and validity of indigenous governments and politics and, as a discipline, to broaden our perspectives.

\section{The Value of Including Native American Perspectives}

While the quincentennial year provided an opportunity for inclusion, it did not provide the only rationale for a focus on indigenous peoples. We must also examine the governments and politics of native peoples because they are an existential part of the historical and contemporary experience of the American political system. They do not represent merely the "interesting natives" of anthropological study; they exist as important players in this political system (both within and without the constitutional system) and the international political system as well.

Besides seeing Native Americans as actors in our own mass democracy, the study of Native American government and politics offers insight into the theoretical morass that has come to define the discipline. As Almond and Coleman noted more than three decades ago, our conceptual scheme has lost its ability to deal adequately even with Western European politics, because of its unnecessary reliance on a legal and institutional vocabulary. They stated:

Even in the absence of this compelling scientific justification for broadening the scope of comparative politics, practical policy motives have forced the modern political scientist to concern himself with the whole range of political systems which exist in the modern world-from African kingdoms and tribal organizations, to traditional oligarchies such as Saudi Arabia, and transitional, modernizing systems such as Burma and India (Almond and Coleman $1960,10)$.

Post-modern theorists extend $\mathrm{Al}$ mond and Coleman's earlier argument for inclusiveness. They, after all, argued for inclusiveness in terms of attempts to develop general theories - as this attempt was understood at the time. Post-modern theory, on the other hand, recognizes that power establishes the very terms of our discourse, and that every regime provides for a politics consonant with itself. In his recent recent American Political Science Review article, Lowi put it succinctly: "The APSA follows Leviathan"' (1992,4).

The political experience of $\mathrm{Na}$ tive Americans demands attention in our common quest to delimit the reality of politics apart from the hegemonic discourses that currently mark the profession. Ironically, the experiences of "the other'"Native Americans, women, African Americans, Latinos, lesbians and gay men, and others-offer us the possibility to penetrate to our subject matter, to evade the intellectual snares and enticements of Leviathan.

Lowi also calls us back to evaluation and judgment. As he puts it, "We confront an unnatural universe that requires judgment and evaluation. Without this, there can be no love of subject, only vocational commitment to method and process"' (Lowi 1992, 5). Certainly, the conquest of the Americas demands critical evaluation.

Nearly 3 million indigenous peoples live in North America, and about 1.9 million live in the United 
States (Wilmer, forthcoming). Sixty-five percent of the native peoples in the United States live in urban areas, and approximately 800,000 Native Americans reside on about 50 million acres of land recognized by the U.S. government as reservations (Burnham 144-145).

In the United States alone, there are more than $\mathbf{5 0 0}$ different native governments, including those on 310 reservations and trust lands (and four trust lands not associated with any reservation), 217 Alaskan village organizations, and native governments that are not formally recognized by the Bureau of Indian Affairs (Presidential Commission on Indian Reservation Economies 1984, 19 and 29). In addition, native peoples in the United States control substantial quantities of vital natural resources: coal, oil, natural gas, uranium and, most important in arid parts of the United States, water (Barsh 1988). These indigenous peoples no longer willingly accept acculturation just as they have never embraced their conquest. Their self-awareness and sovereignty will now make them a force to be reckoned with not only in the United States, but also in the global community.

While some of our undergraduate students will be political science majors interested in the intricacies of government and politics, many of the students we teach are required by their liberal arts or general education curriculum to study political systems in general or American and state government in particular. It is our major opportunity to make an impact on students we will probably see just once in their academic careers; this is the most important reason for the inclusion of indigenous and multicultural perspectives. We can prepare our students to be more inclusive in their own perspectives by providing them with a more accurate history of the Americas, a concept of democratic theory that is inclusive rather than exclusive, and an understanding of community adaptability and development.

But all of these students must have knowledge of the system. We should not be surprised at the continuation of racial conflict if nothing in the socialization process has been changed to enable citizens to understand the diversity of experience.

\section{Treatment of Native Americans in Political Science Texts}

In 1989, Anne Merline McCulloch authored an article that focused on perspectives on Native Americans in political science textbooks. She reviewed a number of texts and concluded that not only is there a neglect of native issues in political science texts, but also that the very paradigms within which we structure our analyses do not allow for the unique place of native peoples and governments (McCulloch 1989, 98). ${ }^{1}$

Unfortunately, our current review of political science texts reveals that neglect of important native issues and contributions continues within the discipline. For this discussion twelve American government texts, ${ }^{2}$ five state and local government texts, ${ }^{3}$ and seven international relations texts ${ }^{4}$ were examined to determine the treatment given to indigenous issues and politics. This investigation revealed a woeful lack of material, which means that the original conquest continues in every schoolroom-especially those with Native American students, since the role of indigenous peoples is absent from any perspective on the development of the American political system.

One of the American government texts did not mention native peoples or issues at all (Ross 1992), and the dominant theme in the eleven texts where Native Americans were mentioned was that $\mathrm{Na}$ tive Americans form a racial/ethnic minority seeking redress in American government through a civil rights approach. Except for three of the texts, the entire topic of native government, politics, and issues generally received no more attention than a scant paragraph or two. Most of the references in these American government texts were to racial discrimination, and eight of them also made reference to civil rights as a concern of $\mathrm{Na}$ tive Americans (Janda, Berry, and Goldman 1992; Keefe, Flanigan, Jones, Ogul, and Spanier 1990; Burns, Peltason, and Cronin 1985; O'Connor and Sabato 1993; Volkomer 1992; Bardes, Shelley, and Schmidt 1992; Brackett 1992; and Burnham 1986). In one text, Native Americans were considered under the heading, "Other Underrepresented Groups," which followed a lengthy discussion of the women's movement (Baradat 1992).

Five of the texts mentioned the historical context of white settlement and the violence directed against Native Americans (Keefe, Flanigan, Jones, Ogul and Spanier; Prewitt, Verba and Salisbury; Burns, Peltason and Cronin; Volkomer; and Baradat). Bardes, Shelley, and Schmidt provided a more understanding perspective. Their text included a three-page section on Native Americans in a chapter on minority rights. They also gave some indication of the scale of violence against native peoples by noting that the original native population was about 10 million during the colonial period and by 1900 was reduced to about one-half million $(1992,139)$. This text also provided a highlight box that discussed the Iroquois Confederacy and its influence on the development of the United States Constitution as well as the wider political culture. Shelly and Schmidt provide the only text that not only included Native Americans as a previously excluded ethnic minority participating in and benefiting from recent civil rights activism and legal movements, but also recognized Native Americans for their cultural and political contributions (1992, 139).

Only three of the texts provided a significant amount of contemporary data on Native Americans. Burns, Peltason, and Cronin, for example, supplied a chronology of U.S. policy toward American Indians, and discussed native activism, including the American Indian Movement, the National Indian Youth Council, the Declaration of Indian Purpose, and sit-ins and fish-ins in pursuit of treaty and fish- 
ing rights. This text also mentioned some contemporary native leaders by name.

Bardes, Shelley, and Schmidt provided comparative data on family income and death rates. They also discussed in some detail issues that were uniquely of concern to Native Americans: appropriation of native lands; treaty rights; removal policies; the Bureau of Indian Affairs; the role of the Supreme Court in delineating native rights; and the Allotment Act and its effect in reducing native-held land (1985, 139-42).

Burnham also discussed political activism, including the American Indian Movement, the recent occupation of Wounded Knee, as well as the Wounded Knee massacre of 1980. This text also provided a chart showing federal Indian reservations by state, number of reservations, tribally owned acreage, population, average unemployment, and the major tribes or native populations in each state $(1986,144)$.

Of the five state and local government texts examined, only the Press and Verburg text mentioned Native Americans. The reference in this text was under the heading, "The Politics of Race and Language," and was made in conjunction with a reference to infant mortality among nonwhites in the United States. This text also noted that, in pursuit of more responsive government, "[r]acial or ethnic groups, such as blacks, Indians, or Chicanos, have used disruptive tactics, including violence" (1991, 165). This lack of attention to native issues and governments ignores the complex problems that face state and local governments when issues like water rights, treaty rights, and native peoples' economic development and sovereignty are in question.

None of the international relations texts included any listings for "indigenous," "aboriginal," or "native" peoples. This is a particularly significant oversight, because representatives of indigenous nations have long engaged in efforts to obtain international protection against and redress for the effects of colonialism. They appealed to the League of Nations in 1923 and persisted for over two decades in an effort to gain access to the United Nations system. In 1971, the Human Rights Commission Subcommittee on Prevention of Discrimination and Protection of Minorities created a Working Group on Indigenous Populations and authorized a long-overdue study of the present situation of indigenous peoples. In 1992, Rigoberta Menchu of Guatemala received the Nobel Peace Prize. In short, there has been a persistent and growing movement of selfawareness among the world's indigenous peoples, including Native Americans.

None of these texts discussed the special relationship that Native American tribes have with the federal government and the unique place they hold due to treaty rights. For the most part, these texts neglected any discussion of the contribution that native peoples have made to the development of the American political system, and they paid little attention to the role of native peoples in contemporary American politics and government.

\section{Including Native Americans in Political Science Courses}

To break this cycle of neglect and place Native American issues and politics in their rightful place in political science courses, we must include a focus on indigenous (and other minority) peoples in all political science courses. This must of course include American government courses, where we will reach many students who will not take other political science courses. However, every subfield of political science should include native topics: courses in judicial politics and law, public administration, federalism, state and local government, international relations, comparative government, and intergovernmental relations. In our courses we must acknowledge both the historical relationships and the continuing presence of native peoples in the American political system.

How can we move from such a limited understanding of indigenous issues to a thoughtful inclusion of these concerns in the whole range of political science courses? Several ways to incorporate native perspectives can be useful, and relevant material can be found in almost any university library. The following discussion includes topics in which native perspectives can be naturally included and sources from which relevant information can be obtained. We have attempted to provide both the general information and the bibliographic resources to encourage political scientists to include native perspectives in a wide variety of political science classes. ${ }^{5}$

Additional information on these topics can be obtained from the Native American Policy Network, which publishes the Native American Policy Network Newsletter. The Newsletter provides information concerning native issues and research activities focused on indigenous topics. The Network was created by a group of political scientists, M.E. Melody and the late Craig Wanner among others, at the 1979 Annual Meeting of the American Political Science Association in order to encourage research relevant to Native American policy issues. Members include Native American leaders, academics from a variety of disciplines, and practitioners.

The Network operates from the conviction that Indian policy involves issues of critical importance not only to the lives of Native Americans and others, but also to the understanding of our own political system. The Network also holds that the Native American policy-making process has not received the kind of scrutiny that it warrants. The central aim of the Network, then, is to help facilitate and increase research in all areas of Native American policy and the policy-making processes. Members of the Network meet each year at the American Political Science Association annual meeting, and the Network sponsors panels and roundtables to provide a forum for examining indigenous politics and government. ${ }^{6}$ 


\section{Native Perspectives in American Government Courses}

The first place that students should encounter native perspectives ought to be in American government courses. Topics such as constitutional formation, governmental structure, federalism, nation-building, interest groups and political parties, political activism, and legal issues all provide areas in which native perspectives can be included. But most important, any discussion of American government must be based on the fact that native peoples inhabited this hemisphere before the European invasion. Originally, North Americans dealt with indigenous peoples as sovereign nations by signing formal treaties with them (Sale 1990). This sets the stage for a fuller understanding of the creation and development of American government.

A study of constitutional formation and history calls for a focus on the philosophical and practical perspectives that influenced America's founders. An understanding of $\mathrm{Na}$ tive American culture and governments reveals that it is not a question of whether, but how much, the colonials were influenced by their contact with Native American peoples. Two examples well illustrate this point. The plan for a confederated union presented by Ben Franklin at Albany in 1754 is remarkably similar to the structure of the Haudenosaunee confederacy-including a republican form of government, a bicameral legislature, and separation of war-making and executive powers (Burton 1988). The structure of the Iroquois confederacy is also pertinent in this regard (Bardes, Shelley, and Schmidt 1992, 139142; Cornell University American Indian Program 1988; Weatherford 1988 and 1991; and Mohawk and Lyons 1992). A discussion of Indian governance can be found in Chaudhuri's Founding America, a text in American political thought (1992).

A study of federalism is essential to an understanding of American government, and any discussion of federalism includes the concept of sovereignty. Native perspectives are especially important in such a discussion, for tribal government sovereignty-and its changing definition through the historical development of the United States-provides a fuller understanding of the idea of federalism and illuminates this difficult concept for students (Deloria and Lytle 1983).

Nation building is another important focus of any study of American government. The native perspective is critical here, since it was the physical expansion into traditional native territories that fostered the growth of the United States. Included in the study of nation building should be a focus on the treaties signed with native nations, the trust relationship and treaty rights that follow from these agreements, and the forced removal and relocation of native peoples from their territories (Deloria 1985; Deloria and Cadwalader 1984; Prucha 1984; Bardes, Shelley, and Schmidt 1992; Burns, Peltason, and Cronin 1985; Brown 1970; Jaimes 1992; and Weatherford 1988 and 1991). 7

A study of political activism and contemporary legal and political issues also provides a forum for inclusion of indigenous perspectives. Native American peoples and governments have been involved in political activism and the pursuit of legal rights throughout the history of the United States. Since indigenous peoples have treaty rights upon which to base their legal actions, they serve as a unique group among ethnic and racial minorities in the United States. References to Native Americans most often found in American government texts were those made in relation to the civil rights movement and the direct action tactics of native peoples in the 1960 s and 1970 s. In addition, other texts provide useful material for inclusion in such a study (Cornell 1988; Legters and Lyden 1992; Price and Clinton 1983; and Wilkinson 1987).

\section{Native American Perspectives in State and Local Government Courses}

Increasingly, there are more interactions between state and local governments and tribal governments. Federal policy has finally allowed tribes to assert rights of self-determination and self-governance. Tribes have been increasingly willing to assert treaty rights, as well as use sovereign governmental powers like taxation. Since these actions do not always coincide with the plans of non-native state and local governments, conflicts have been persistent. Current disputes over gambling on reservations provide another example. An understanding of treaty rights, tribal sovereignty, native needs for economic development, and cultural differences may reduce the level of conflict and perhaps foster cooperative enterprise (Bardes, Shelley, and Schmidt 1992, 139142; Burnham 1986, 144-145; Deloria 1985; Deloria and Lytle 1983; Prucha 1984; Jaimes 1992).

\section{Native Perspectives in Judicial Process and American Law Courses}

Indian law represents a special branch of American jurisprudence: it applies only to Native Americans because of their status as aboriginal occupants in a territory where a new legal and political system was imposed. However, native peoples are also protected by anti-discrimination laws that protect all minorities. In addition, the rights of indigenous peoples have increasingly been recognized in international law as well. Thus, the legal status of Native Americans intersects with three other areas of law present in the American system: law aimed at protecting minorities from discrimination, Indian law, and international law in the form of internationally recognized human rights.

Indigenous peoples and governments have historically turned to the courts to assert their claims to land, water, natural resources, and civil rights. And it is usually in the courts that at least formal recognition of native rights and claims have been upheld, if at all. The examination of such claims, as well as the special trust relationship held by indigenous peoples, is an appropriate focus for sections of 
courses dealing with judicial process and American law. Such an examination is especially appropriate in the context of a study of the courts as political instruments-for often the courts have reflected and enforced the public view that indigenous rights can be ignored or negated depending on the economic, political, or territorial needs of the dominant culture (Bennett 1978; Brown 1970; Deloria 1985; Deloria and Cadwalader 1984; Deloria and Lytle 1983; Hoebel 1976; Jaimes 1992; Legters and Lyden 1992; Price and Clinton 1983; and Wilkinson 1987).

\section{Native Perspectives in Public Administration Courses}

The issues of federalism, intergovernmental relations, and administration of public institutions serve as critical parts of public administration courses. These courses also provide a forum for inclusion of native perspectives for two reasons. First, indigenous governmental institutions are the legitimate subject of study, since they are functioning governments within the United States-and often functioning in close proximity to state and local governments as well as the national government. Indigenous governments can provide a comparative perspective on public administration. Second, indigenous governments increasingly interact with national, state, and local governments, and an understanding of their history, structure, and processes can be critical for those involved in such interactions (Brown 1970; Deloria 1985; Deloria and Lytle 1983; Legters and Lyden 1992; Wilkinson 1987).

Additionally, public administration courses that specifically address issues of Native American governance should be developed in light of the growing number of $\mathrm{Na}$ tive American people working in government positions in their own communities. Native American governments on 218 federal and state reservations employ thousands of people. Many tribes own and operate gaming enterprises that are generating large revenues.
These revenues are used to fund and expand social services including health care, alcohol and drug abuse treatment, housing programs, day care programs, libraries, and recreational projects (Wilmer 1994).

The number of Native Americans working in the public sector of their own governments will only increase. Secretary of Interior Bruce Babbitt has emphasized that the federal government should view native governments as local governments that are competent and capable of governing themselves. Native American governments are unique among local governments since they possess certain sovereign powers. Babbitt also advocates expanding the direct relationship between the federal government and native governments by making more use of contracting for self-determination to provide native governments with more discretion in program development and administration (National Native News, 1993). Public administration is a field of study at both the undergraduate and graduate levels that has enormous practical value for college-bound native students.

\section{Native Perspectives in International Relations Courses}

The topic of indigenous peoples-those who have continuously occupied areas conquered by Europeans over the past five centuries and who seek to maintain their traditional cultures and social institutions-can naturally be incorporated into courses in international relations, international relations theory, international law, international organizations, and international human rights. Since our students cannot remain insulated within a North American perspective but, rather, must be educated as international citizens, they should understand as well the native perspectives in law, civil rights, economic development, environmental policy and law, and sovereignty in native governments.

Indigenous perspectives can provide a focus in any of these areas, and inclusion of native perspectives will provide not only a more inclu- sive and accurate perception of international relations, but also prepare students with a better knowledge of past events and current interactions as well as future possibilities. Such knowledge can make our students better decision makers in the global community (Anaya 1989; Akwesasne Notes, 1986, Barsh and Henderson 1980; Bennett 1978; Burger 1987; Jaimes and Churchill 1992; Indian Law Resource Center, 1988; and Wilmer 1993b). The United Nations, for example, recognized 1993 as the Year of the Indigenous Peoples (Wilmer 1993a).

\section{Native Perspectives in Comparative Government and Minority Politics Courses}

While traditionally political scientists have looked outside the United States for topics in comparative government, native governments provide a rich and diverse set of systems for comparative study. These governments can be examined in both an historical and contemporary context, and they provide examples of governmental processes that can be observed in operation, since they operate within the United States and in close proximity to many other governmental units. The existence of these nations within the United States political system should not be ignored in any study of comparative government (Cassidy and Bish 1989; Cornell 1988; Deloria and Lytle 1983; Fleras and Elliott 1992; O’Brien 1990; and Wilkinson 1987).

Minority politics courses also provide a forum for the analysis and discussion of native governments, political processes, and issues. While many of the issues that concern other minorities (e.g., political power, voting rights, representation) are also of concern to native peoples, Native Americans hold a unique place in this political system. They operate their own governmental systems based on their ownership of and jurisdiction over tribal lands. Their unique relationship to the federal government, based in treaty rights and reflected 
in Indian law, also makes native perspectives an essential part of any course in minority politics. The analysis of recent court cases that define tribal governmental authority provide rich examples for case studies in minority political action (Cassidy and Bish 1989; Cornell 1988; Deloria and Lytle 1983; and Wilkinson 1987). Finally, native governments can provide examples of consensual decision making and its political consequences as well as different understandings of the nature of politics itself (Melody 1980a).

\section{Native Perspectives in Political Theory Courses}

Courses in political theory have traditionally ignored any mention of indigenous governments or political process. There is much value in broadening our perspectives on political theory beyond the European tradition in which it is captured, and indigenous governments and processes provide much material for inclusion in theory classes. The classic focus on topics such as authority, power, governance, and participation is enriched by including material from indigenous governments, for they represent alternative perspectives and experiences (Melody 1980).

Including the experience of indigenous peoples will provide students not only with a fuller understanding of different applications of these theories, but will also allow for a comparative analysis of theories as well. The study of consensual decision making in native governments, comparable to that in the cabinet of the United Kingdom, provides an example of how native perspectives can be productively incorporated into theory classes (Barsh and Henderson 1980; Chaudhuri 1992; Cornell University 1988; Grinde and Johnson 1991; and Weatherford 1988).

\section{Conclusions}

We must prepare our students to be knowledgeable participants in local, state, national, and international communities. We cannot be good guides in this process unless we thoroughly depict how these communities developed through time, what institutions, players, and processes interact in the contemporary period, and the kind of possibilities that exist for the future.

We have long neglected to include the experiences and institutions of indigenous peoples in the American political system, and we have mainly relegated native issues to "interesting sidelights" in our discipline. While the Columbus quincentennial provided some fleeting awareness of native issues, we must make a concerted effort to include the experiences and perspectives of indigenous peoples across the gamut of political science courses: we will find new material for comparison, for understanding, and for tolerance of diversity.

But we cannot forget that our responsibility goes beyond teaching and research, for "[p]olitical science as a discipline may not have a direct impact on the policies of government or the opinions of politicians, but it does structure the way knowledge and politics are perceived. We cannot expect our political leaders to be sophisticated and educated about Indian tribal politics if the discipline of political science is itself ignorant in this area" (McCulloch 1989, 97). As Lowi suggested, what is at stake, at least partially, is genuine political knowledge, and this episteme cannot serve as a function of conquest and exclude a stigmatized "other."

\section{Notes}

1. McCulloch's review revealed that only one American government text, Fred Harris's America's Democracy: The Ideal and the Reality, (Glenview, IL: Scott, Foresman, 1986) treated the Indian tribal structure as another form of government, and thus discussed "Indian tribes not only in the chapter on civil rights, but also in those sections on civil liberties, interest groups, federalism, the judiciary. and public participation." (pp. 95-96). Harris himself has a broad background in Indian culture and politics.

2. Janda, Berry, and Goldman 1992; Prewitt, Verba and Salisbury 1987; Keefe, Flanigan, Jones, Ogul, and Spanier 1990; Stone and Barke 1985; Lipsitz 1986; Burns, Pelta- son, and Cronin 1985; O'Connor and Sabato 1993; Volkomer 1992; Bardes, Shelley, and Schmidt 1992; Baradat 1992; Burnham 1986; Ross 1992.

3. Houseman 1986; Press and Verberg 1991; Bingham and Hedge 1991; Dye 1988, and Luttbeg 1992.

4. Jones and Rosen 1982; Chan 1984; Papp 1991; Kegley and Wittkopf 1993; Russett and Starr 1992; Pearson and Rochester 1988; and Ray 1992.

5. The authors gratefully acknowledge the contribution made by their colleagues in the compilation of this material. Many have included native perspectives in classes and have shared their knowledge and experience. We thank Gerald Alfred, Cornell University, for the "Note on Terminology" in his syllabus for a course on aboriginal selfgovernment; Joyotpaul Chaudhuri, Arizona State University, for sharing perspectives on native topics in political theory and comparative government courses, as well as his conviction that "American Indian topics can be interwoven into every subfield in political science without exception"; Anne Merline McCulloch, Columbia College, for materials on native perspectives in federalism; Steve Sachs, Indiana University Purdue University Indianapolis, for bibliographic information from his courses in law and society and comparative government; Richard D. Shingles, Virginia Polytechnic Institute and State University, for perspectives and a syllabus from his course on minority politics; and David Wilkins, University of Arizona, for his editorial perspectives on this article.

6. Information on the Native American Policy Network may be obtained from M. E. Melody, Network Newsletter Editor, Department of History and Political Science, Barry University, Miami, Florida; and Network program organizers Maggi Murdock, University of Wyoming, UW/CC Center, Casper, Wyoming; and Diane Lazear, University of Wisconsin-Oshkosh, Oshkosh, Wisconsin.

7. Francis Paul Prucha's The Great Father: The United States Government and the American Indian provides a compilation of the most important documents outlining policies pursued by the United States government in its relations with native peoples. It includes not only the texts of major treaties and Acts of Congress (such as the Dawes Allotment Act of 1883, the Indian Citizenship Act of 1924, and the Indian Reorganization Act of 1934), but also includes excerpts from the personal writings of statesmen, United States Supreme Court decisions, presidential speeches, and many reports from Indian Commissioners and the Bureau of Indian Affairs.

\section{References}

Akwesasne Notes. 1986. Basic Call to Consciousness. Rooseveltown, NY: Akwesasne Notes.

Almond, Gabriel, and James Coleman. 1960. The Politics of Developing Areas. Princeton: Princeton University Press.

Anaya, James S. 1989. "The Rights of In- 
digenous Peoples and International Law in Historical and Contemporary Perspective." Hanvard Law Review.

Baradat, Leon P. 1992. Understanding American Democracy. New York: HarperCollins.

Bardes, Barbara, Mack Shelley, and Stefen Schmidt. 1992. American Government and Politics Today: The Essentials. New York: West.

Barsh, R. L. 1988. "Indian Resources and the National Economy: Business Cycles and Policy Cycles." Policy Studies Journal. 16(4) Summer 799-825.

Barsh, R. L., and James Youngblood Henderson. 1980. The Road: Indian Tribes and Political Liberty. Berkeley: University of California Press.

Bennett, Gordon. 1978. Aboriginal Rights in International Law. London: Royal Anthropological Society of Great Britain and Ireland.

Bingham, Richard and David Hedge. 1991. State and Local Government in a Changing Society. New York: McGraw Hill.

Brackett, Leon P. 1992. Understanding American Democracy. New York: HarperCollins.

Brown, Dee. 1970. Bury My Heart at Wounded Knee. New York: Holt, Rhinehart and Winston.

Burger, Julian. 1987. Report From the Frontier: The State of the World's Indigenous Peoples. London: Zed Books.

Burnham, Walter Dean. 1986. Democracy in the Making: American Government and Politics. Englewood Cliffs: Prentice-Hall.

Burns, James MacGregor, J.W. Peltason, and Thomas Cronin. 1985. Govemment by the People. Englewood Cliffs, New Jersey; Prentice-Hall.

Burton, Bruce. 1988. "The Iroquois Had Democracy Before We Did." CUAIP.

Cassidy, Frank, and Robert L. Bish. 1989. Indian Government: Its Meaning in Practice. Lantzville, B.C.: Oolichan Books.

Chan, Steve. 1984. International Relations in Perspective: The Pursuit of Security, Welfare and Justice. New York: Macmillan.

Chaudhuri, Joyotpaul. 1992. Founding America: The Political Legacy of Rights, Religion, Commerce and Diversity. Dubuque, IA: Kendall-Hunt.

Cornell University American Indian Program. 1988. The Indian Roots of American Democracy. Summary of Proceedings of 1988 Symposia.

Cornell, Stephen. 1988. The Return of the Native: American Indian Political Resurgence. Oxford University Press: New York.

Deloria, Vine. 1985. American Indian Policy in the Twentieth Century. Norman: University of Oklahoma Press.

Deloria, Vine, and Sandra Cadwalader. 1984. The Aggressions of Civilization: American Indian Policy Since the 1880s. Philadelphia: Temple University Press.

Deloria, Vine, and Clifford Lytle. 1983. The Nations Within: The Past and Future Status of American Indian Sovereignty. New York: Pantheon Books.

Dye, Thomas. 1988. Politics in States and
Communities. Englewood Cliffs: Prentice Hall.

Fleras, Augie, and Jean Leonard Elliott. 1992. The Nations Within: AboriginalState Relations in Canada, the United States and New Zealand. Oxford University Press: Toronto.

Frideras, James S. 1988. Native Peoples in Canada: Contemporany Conflicts. 3rd Edition. Scarborough, Ontario: PrenticeHall Canada.

Grinde, Donald A. Jr., and Bruce E. Johnson. 1991. Exemplar of Liberty: Native America and the Evolution of Democracy. Los Angeles: American Indian Studies, University of California Los Angeles.

Hoebel, E. Adamson. 1976. The Law of Primitive Man. New York: Atheneum.

Houseman, Gerald L. 1986. State and Local Government: The New Battleground. Englewood Cliffs, NJ: Prentice-Hall.

IWGIA Newsletter. 1992. "Rigoberta Menchu, Nobel Peace Prize Winner,' No. 2. Copenhagen; International Work Group for Indigenous Affairs.

Indian Law Resource Center. 1988. Indian Rights, Human Rights: Handbook for Indians on International Human Rights Complaint Procedures.

Jaimes, M. Annette, and Ward Churchill, eds. 1992. The State of Native America: Genocide, Colonization and Resistance. Boston: South End Press.

Jaimes, M. Annette. ed. 1992. Fantasies of the Master Race: Literature, Cinema and the Colonization of American Indians. Monroe, ME: Common Courage Press.

Janda, Keith, Jeffrey Berry, and Jerry Goldman. 1992. The Challenge of Democracy: Government in America. Boston: Houghton Mifflin.

Jones, Walter S., and Steven Rosen. 1982. The Logic of International Relations. Boston: Little, Brown and Company.

Jorgensen, Joseph G., ed. 1984. Native Americans and Energy Development II. Cambridge, MA: Anthropology Resource Center.

Keefe, William, Abraham W. Flanigan, Charles O. Jones, Morris Ogul, and John Spanier. 1990. American Democracy: Institutions, Politics and Policies. New York: Harper and Row.

Kegley, Charles W., and Eugene R. Wittkopf. 1993. World Politics: Trends and Transformation. New York: St. Martin's Press.

Legters, Lyman H., and Freemont J. Lyden. 1992. Native Americans and Public Policy. Pittsburgh: University of Pittsburgh Press.

Lipsitz, Lewis. 1986. American Democracy, New York: St. Martin's Press.

Lowi, Theodore J. 1992. "The State in Political Science: How We Become What We Study." American Political Science Review 86(1) 1-7.

Luttbeg, Norman R. 1992. Comparing States and Communities: Politics, Govermment and Policy in the United States. New York: HarperCollins.

McCulloch, Anne Merline. 1989. "Perspectives on Native Americans in Political
Science." Teaching Political Science: Politics in Perspective. 16(3), 93-98.

Melody, Michael E. 1980. “On the Tyranny of Concepts." Paper presented at the annual meeting of the Southwestern Social Science Association, Houston, TX.

Melody, Michael E. 1980a. "Lakota Myth and Government: The Cosmos as the State." American Indian Culture and Research Joumal 4(3), 1-19.

Melody, Michael E., and Margaret Maier Murdock. 1987. "Native Americans and the Practice of Political Science." Paper presented at the Western Social Science Association Annual Meeting, El Paso, TX.

Mohawk, John, and Oren Lyons. 1992. Exiled in the Land of the Free. Santa Fe: Clear Light Publishing.

National Native News. 1993. National Public Radio. August 26, 1993.

O'Brien, Sharon. 1989. American Indian Tribal Government. Norman, OK: University of Oklahoma Press.

O'Connor, Karen, and Larry Sabato. 1993. American Government: Roots and Reform. New York: Macmillan.

Papp, Daniel S. 1991. Contemporary International Relations. New York: Macmillan.

Parlow, Anita. 1988. Cry, Sacred Ground: Big Mountain, U.S.A. Washington, D.C.: Christic Institute.

Paisano, Edna, et. al. 1991. American Indian and Alaska Native Areas 1990. Washington, D.C.: Bureau of Census.

Pearson, Frederic S., and J. Martin Rochester. 1988. International Relations: The Global Condition in the Late Twentieth Century. New York: Newberry Award Records.

Presidential Commission on Indian Reservation Economies. 1984. Report and Recommendations to the President of the United States. Washington, D.C.: Government Printing Office.

Press, Charles, and Kenneth Verberg. 1991. State and Community Governments in a Dynamic Federal System. New York: HarperCollins.

Prewitt, Kenneth, Sydney Verba, and Richard Salisbury. 1987. An Introduction to American Government. New York: Harper and Row.

Price, Monroe E., and Robert N. Clinton. 1983. Law and the American Indian: Readings, Notes and Cases. Charlottesville, VA: Michie Company.

Prucha, Francis Paul. 1984. The Great Father: The United States Government and the American Indian. Lincoln: University of Nebraska Press.

Ray, James Lee. 1992. Global Politics. Boston: Houghton Mifflin.

Ross, Robert. 1992. American National Government: Institutions, Policy and Participation. Guilford, CT: Dushkin.

Russett, Bruce, and Harvey Starr. 1992. World Politics: The Menu for Choice. New York: W.H. Freeman.

Sale, Kirkpatrick. 1990. The Conquest of Paradise. New York: Knopf.

Stone, Alan, and Richard P. Barke. 1985. Governing the American Republic: Economics, Law and Policies. New York: St. Martin's Press. 
Volkomer, Walter E. 1992. American Government. Englewood Cliffs, NJ: PrenticeHall.

Weatherford, Jack. 1988. Indian Givers: How the Indians of the Americas Trans formed the World. New York: Fawcett Columbine.

Weatherford, Jack. 1991. Native Roots: How the Indians Enriched America. New York: Crown Publishers.

Wilkinson, Charles. 1987. American Indians, Time and the Law: Native Societies in a Modern Constitutional Democracy. New Haven: Yale University Press.

Wilmer, Franke. 1993a. The Indigenous Voice in World Politics: Since Time Immemorial: Newbury Park, CA: Sage Publishers.

Wilmer, Franke. 1993b. "The International Political Activism of Indigenous Peoples in the World System." In Bernard Schechterman and Martin Slann, ed. The Ethnic Dimension in International Relations. Westport, CT: Praeger Publishers.
Wilmer, Franke. 1994. "Indian Gaming: Players and Stakes." Monograph. Bozeman, Montana: State and Local Government Center, Montana State University.

\section{About the Authors}

Franke Wilmer is assistant professor of international relations and political science at Montana State University. She has recently published The Indigenous Voice in World Politics: Since Time Immemorial. She has received a grant from NEH to study Iroquois politics and political theory.
M. E. Melody is a professor at Barry University. He studied under Edward Goerner at the University of Notre Dame. A founding member of the Native American Policy Network, he has edited its newsletter for the last thirteen years. Publications include a bibliographical monograph on the Apaches in 1977 and The Apaches (Chelsea House, 1989).

Margaret Maier Murdock is a professor at the University of Wyoming and dean of the university's Casper College Center. She has been program organizer of the Native American Policy Network since 1981. Her research has included articles on Native American issues, as well as judicial process. 